\title{
Comparison of Monascus purpureus growth, pigment production and composition on different cereal substrates with solid state fermentation
}

\author{
Ignatius Srianta ${ }^{\mathrm{a}, \mathrm{b}, *}$, Elok Zubaidah $^{\mathrm{c}}$, Teti Estiasih ${ }^{\mathrm{c}}$, Mamoru Yamada ${ }^{\mathrm{d}, \mathrm{e}}$, Harijono $^{\mathrm{c}}$ \\ a Doctorate Program of Agricultural Product Technology, Faculty of Agriculture, Brawijaya University, Jalan Veteran, Malang 65145, Indonesia \\ b Department of Food Technology, Faculty of Agricultural Technology, Widya Mandala Catholic University Surabaya, Jalan Dinoyo 42-44, Surabaya 60625, \\ Indonesia \\ ' Department of Agricultural Product Technology, Faculty of Agricultural Technology, Brawijaya University, Jalan Veteran, Malang 65145, Indonesia \\ d Department of Biological Chemistry, Faculty of Agriculture, Yamaguchi University, 1677-1 Yoshida, Yamaguchi 753-8515, Japan \\ e Applied Molecular Bioscience, Graduate School of Medicine, Yamaguchi University, Ube 755-8505, Japan
}

\section{A R T I C L E I N F O}

\section{Article history:}

Received 17 April 2016

Accepted 23 May 2016

Available online 24 May 2016

Keywords:

Monascus pigment

Solid state fermentation

Rice

Corn

Sorghum

LC-MS

\begin{abstract}
A B S T R A C T
The growth and pigment production of Monascus purpureus during 14 days solid state fermentation on different cereal substrates i.e. rice, corn, whole sorghum grain (WSG), dehulled sorghum grain (DSG) and sorghum bran (SB); and pigment composition of the fermented-products have been evaluated. Fungal biomass was used as a basis of its growth. Pigment content was measured by using spectrophotometer and thin-layer chromatography, and its composition was analyzed by using liquid chromatography coupled with tandem mass spectrometry. M. purpureus grew faster on rice substrate than did on other substrates. Production of pigments was observed at the end of logarithmic phase on all substrates tested. Similar pigment compounds were found on all substrates and the highest production of pigments was on rice, followed by DSG $>$ WSG $>$ Corn $>$ SB. Twelve pigments, six of which were well-known, were detected on the Monascus-fermented products at different levels. Among those, Monapilol B, found in Monascus-fermented dioscorea, was found. On all cases, the red pigment Rubropunctamine was the major one (57-87\%), except on SB substrate which produced Yellow II as the major one. Interestingly, fermented-DSG contained a large amount of Rubropunctatin compared to other fermented products. Among the non-rice substrates, DSG is the most potential substrate, on which the fungus exhibited the highest growth and pigment production. These data suggest that the fermented products are good candidates for development of natural food colorant, food supplement, functional food and or medicine with antiinflammation, anticancer and antimicrobial activities.
\end{abstract}

(c) 2016 Elsevier Ltd. All rights reserved.

\section{Introduction}

Monascus purpureus, an edible fungus, has been used in solid state fermentation for centuries in Asian countries. Rice is the common substrate of the Monascus-solid state fermentation, and the Monascus-fermented rice has been widely consumed by people in China, Japan and South East Asian countries (Dufossé et al., 2005; Feng et al., 2012). Corn and sorghum (whole sorghum grain (WSG), dehulled sorghum grain (DSG), and sorghum bran (SB)) are non-rice cereals as potential alternative substrates for the

\footnotetext{
* Corresponding author at: Department of Food Technology, Faculty of Agricultural Technology, Widya Mandala Catholic University Surabaya, Jalan Dinoyo 42 44, Surabaya 60625, Indonesia.

E-mail address: srianta_wm@yahoo.com (I. Srianta).
}

Monascus-solid state fermentation (Kraboun et al., 2013; Kongbangkerd et al., 2014; Srianta and Harijono, 2015).

During the solid state fermentation, M. purpureus produces various secondary metabolites, mainly pigment. The Monascus pigment is a mixture of red, orange and yellow compounds, which are classified into polyketide. Monascin and Ankaflavin (yellow pigments); Rubropunctatin and Monascorubrin (orange pigments); Rubropunctamine and Monascorubramine (red pigments) are six well-known Monascus-pigments. Monascus fungi synthesize the pigments through polyketide biosynthesis pathway, in which polyketide synthase and fatty acid synthase play essential roles (Juzlova et al., 1996; Hajjaj et al., 2000). Different carbon sources seem to affect the pigment production (Carvalho et al., 2007; Nimnoi and Lumyong, 2011).

In the application, the Monascus pigment has been used as 
natural food colorant, food supplement and traditional medicine. As a natural food colorant, red pigments as well as the yellow pigments have been widely used in food industries e.g. meat, edible oil, biscuit, bread, cakes and beverages (Srianta et al., 2014). Moreover, bioactivities, such as antiinflammation, anticancer, antimicrobial, antidiabetes and antiobesity, of isolated Monascus pigments have been reported (Feng et al., 2012). The six wellknown pigments inhibit inflammation (Akihisa et al. (2005b) and Monascin, Ankaflavin, Rubropunctatin, Rubropunctamine, Monascorubramine and Monapilol A-D possess anticancer activity (Akihisa et al., 2005a, 2005b; Hsu et al., 2011; Knecht and Humpf, 2006; Su et al., 2005; Zheng et al., 2010). Antimicrobial activities of Rubropunctatin and Monascorubrin against bacteria, yeast and filamentous fungi (Martinkova et al., 1995); and of red and orange pigments against some pathogenic bacteria (Vendruscolo et al., 2014) have been found. Monascin has been reported as a potential antiobesity through reducing triglyceride accumulation (Jou et al., 2010) and possesses a therapeutic potential on diabetes (Shi et al., 2012). Analysis of pigment composition is thus important for prediction of the potential of fermented materials and their application.

Concerning the analysis of pigment composition, Miyake et al. (2005) have developed a simple and sensitive liquid chromatography-mass spectrometry (LC-MS) method for the detection of $\mathrm{M}+\mathrm{H}$ ion of pigment compounds to estimate their contents, and detected 11 pigments in different Monascus strains grown under various culture conditions. In potato dextrose broth medium, $M$. purpureus NBRC4478 produced mainly Rubropunctatin, $\mathrm{Ru}-$ bropunctamine and Monascin, while another strain, $M$. purpureus SM50 produced a range of pigments with Rubropunctatin, Ankaflavin and Monascin as major pigments. M. pilosus NBRC4520 produced mainly Xanthomonascin A and Monascorubrin in the potato dextrose broth medium, but mainly Rubropunctatin in a medium containing glucose, glycerol and peptone (Miyake et al., 2008).

The objective of the research was to compare the growth of $M$. purpureus M9 and pigments production during solid state fermentation on different cereal substrates: polished rice, corn, whole sorghum grain (WSG), de-hulled sorghum grain (DSG) and sorghum bran (SB); and pigment composition of the Monascusfermented products. Such a comparison study was never been reported elsewhere.

\section{Materials and methods}

\subsection{Microorganism}

M. purpureus was isolated from commercial Monascus-fermented rice (MFR) and identified as M. purpureus M9 (NCBI Accession Number: HM188425.1). M. purpureus culture was maintained on Potato Dextrose Agar (PDA) slant and sub-cultured monthly. M. purpureus starter was prepared by inoculating $M$. purpureus culture stock onto a PDA slant, incubated at $30^{\circ} \mathrm{C}$ for 7 days, and then used for solid state fermentation.

\subsection{Solid state fermentation}

Substrates of rice, corn, WSG, DSG and SB were separately prepared. About $20 \mathrm{~g}$ of each substrate in a jar was added with $15 \mathrm{~mL}$ distilled water and sterilized at $121^{\circ} \mathrm{C}$ for $20 \mathrm{~min}$ Solid state fermentation was carried out by inoculation of $1.5 \mathrm{~mL}$ of $M$. purpureus starter culture containing $5 \times 10^{5}$ spores $/ \mathrm{mL}$ into the sterilized substrate. It was then incubated at $30{ }^{\circ} \mathrm{C}$ for 14 days. A sample of fermented material was taken daily, dried at $45^{\circ} \mathrm{C}$ for $24 \mathrm{~h}$, and analyzed for the biomass level and pigments.

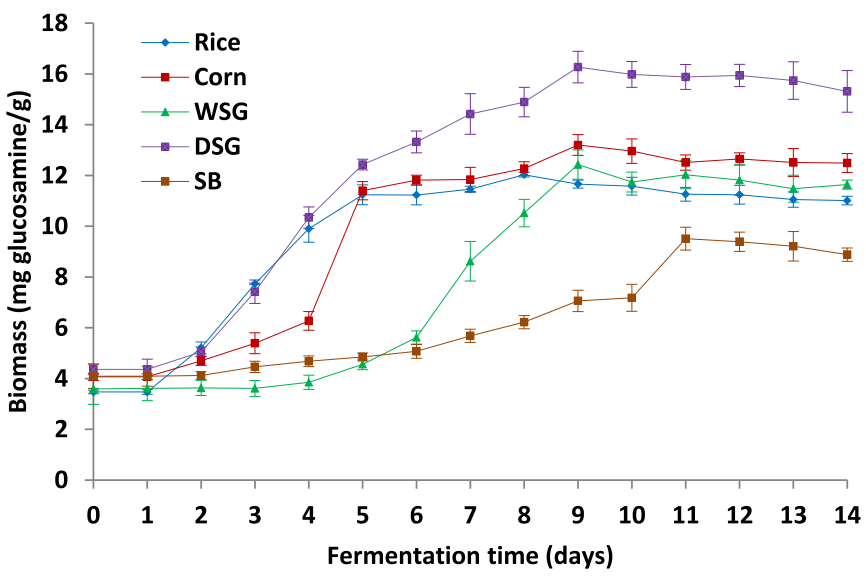

Fig. 1. Growth of M. purpureus on different substrates. Solid state fermentation was carried out in the same conditions $\left(30^{\circ} \mathrm{C}, 14\right.$ days $)$.

\subsection{Biomass estimation}

The fungal biomass was estimated by determining the amount of N-acetyl glucosamine released by acid hydrolysis of chitin, present in the mycelia cell wall (Babitha et al., 2006). Chitin hydrolysis was carried out by using $10 \mathrm{M} \mathrm{HCl}$ and autoclaving at $130{ }^{\circ} \mathrm{C}$ for $2 \mathrm{~h}$. The hydrolysate was neutralized to $\mathrm{pH} 7.0$, mixed with acetyl acetone reagent and followed by Ehrlich reagent. The optical density was measured at $530 \mathrm{~nm}$ against the reagent blank. $\mathrm{N}$-acetyl glucosamine (Sigma Aldrich Co. LLC) was used as a standard.

\subsection{Pigment extraction and analysis}

An accurately weighed fermented matter of about $0.1 \mathrm{~g}$ each was transferred into a tube and mixed with $2 \mathrm{~mL}$ of $75 \%$ ethanol. The mixture was treated in an ultrasonic bath for $60 \mathrm{~min}$, followed by centrifugation at $3000 \mathrm{rpm}$ for $15 \mathrm{~min}$. The solid was re-extracted twice by the same procedure. The collected supernatant was mixed with $75 \%$ ethanol until $10 \mathrm{~mL}$ in a volumetric flask

Pigments analysis of the extracts was carried out by using three methods i.e. spectrophotometry, thin layer chromatography (TLC) and liquid chromatography coupled with tandem mass spectrometry (LC-MS/MS). Spectrophotometry and TLC method was performed for monitoring pigments production during fermentation, while LC-MS/MS for analysis of pigment composition of the fermented-products.

The absorbance of pigment extracts was measured by using UV-vis spectrophotometer at $400 \mathrm{~nm}, 470 \mathrm{~nm}$ and $500 \mathrm{~nm}$. The results were expressed as absorbance unit at the corresponding wavelength per gram (AU/g). TLC method was performed according to Nimnoi and Lumyong (2011). Ethanol extract of $3 \mu \mathrm{L}$ was applied onto a Silica Gel 60 F254 plate (Merck, Germany) and pigments were separated with a mobile phase consisting of chloroform:methanol:water $=90: 25: 4$.

Pigment compounds were determined according to Miyake et al. (2008) with some modifications. The analysis was conducted by LC-MS/MS with an EMS mode using the 3200 Q-TRAP LC-MS/ MS System (AB Sciex, Framingham, MA, USA) equipped with a Prominence UFLC (Shimadzu, Kyoto, Japan). Pigments were separated on a Mightysil RP18 column $(150-\mathrm{mm} \times 2-\mathrm{mm}$ i.d.) with a linear gradient of mobile phase of acetonitrile-water containing $0.1 \%$ formic acid $(60: 40, \mathrm{vol} / \mathrm{vol})$ to acetonitrile-water containing $0.1 \%$ formic acid (100:0, vol $/ \mathrm{vol})$; flow rate of $0.2 \mathrm{~mL} / \mathrm{min}$; oven temperature of $40^{\circ} \mathrm{C}$; run time for $25 \mathrm{~min}$. Pigment compounds were detected by MS/MS using electro-spray ionization in the positive ion mode (IS: 2000; CUR: 40; CAD: set to 'high'; TEM: 

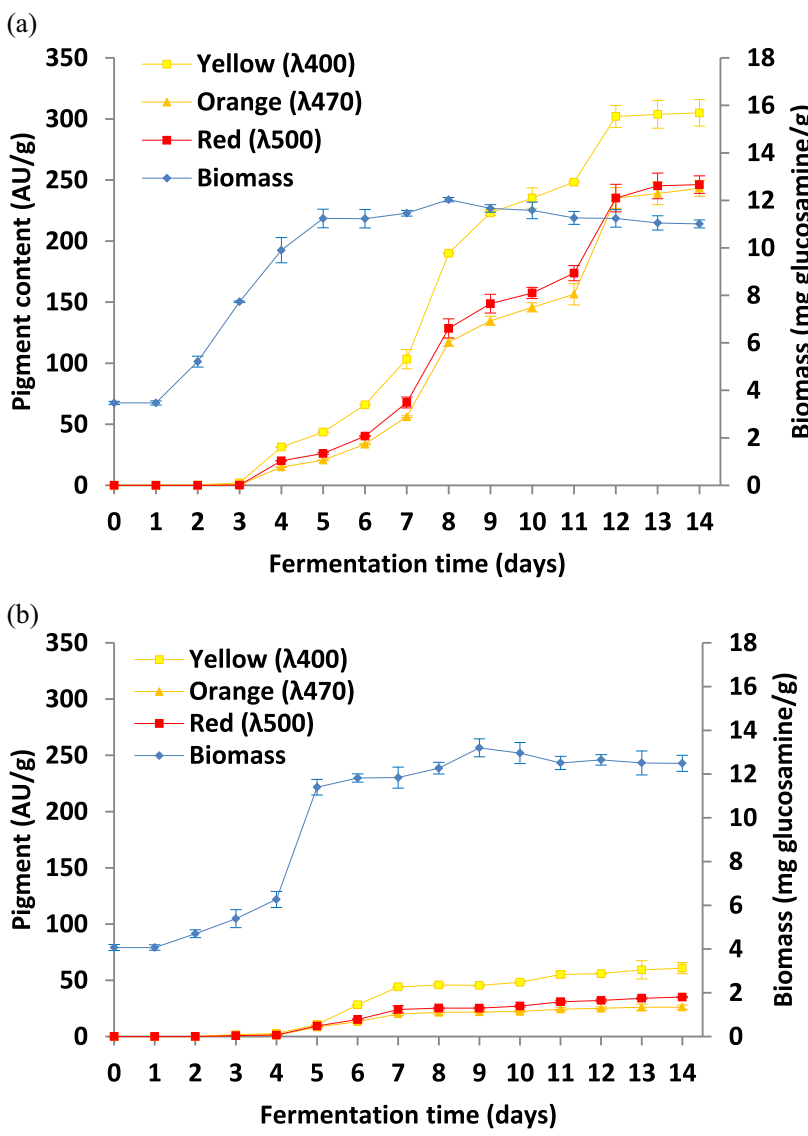

(c)

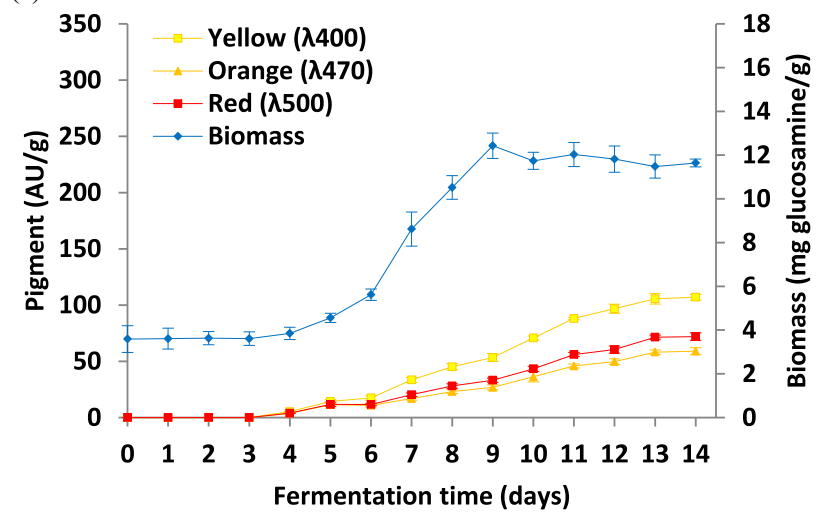

(d)

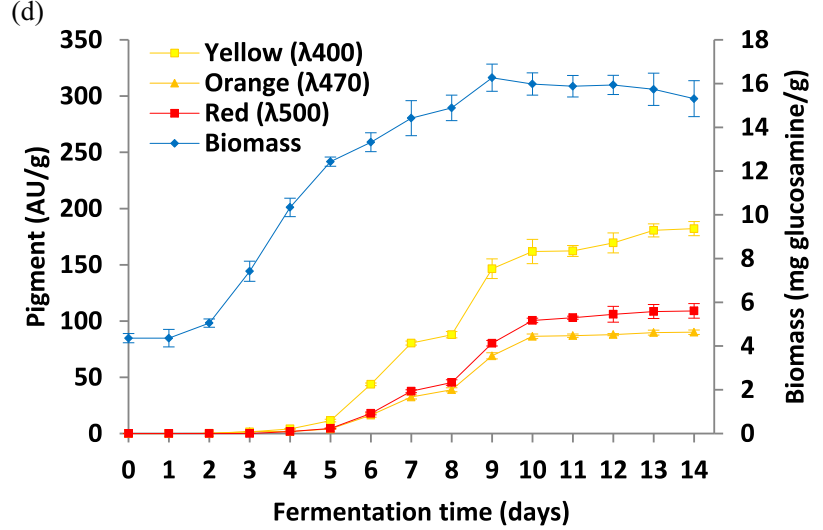

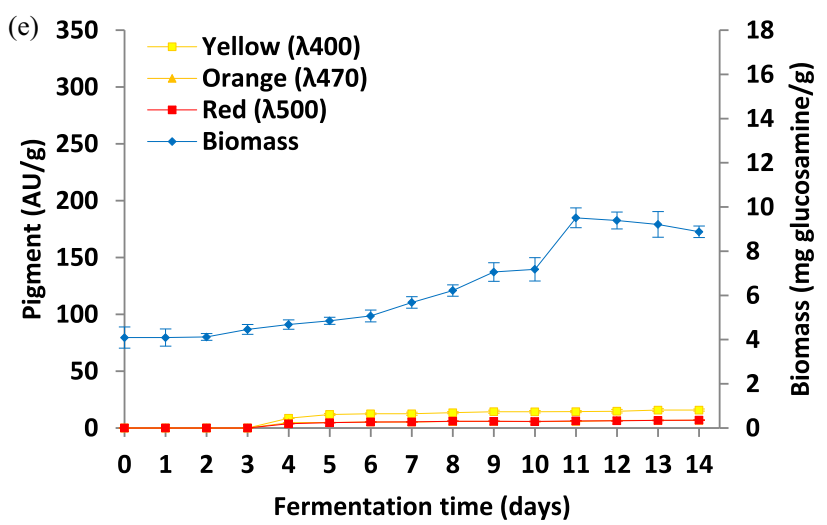

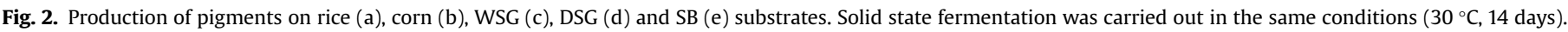

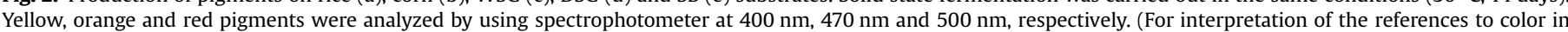
this figure legend, the reader is referred to the web version of this article.)

250; GS1: 50; GS2: 80 , scan range: $m / z 100$ to 1000 , scan speed: $4000 \mathrm{Da} / \mathrm{s})$. Data analysis was performed by using Analyst 1.5.1. software version. Each $\mathrm{M}+\mathrm{H}$ ion was detected as Rubropunctatin $\left(\mathrm{C}_{21} \mathrm{H}_{22} \mathrm{O}_{5}, \quad \mathrm{MW}=354.40\right), \quad$ Monascorubrin $\quad\left(\mathrm{C}_{23} \mathrm{H}_{26} \mathrm{O}_{5}\right.$, $\mathrm{MW}=382.46)$, Rubropunctamine $\left(\mathrm{C}_{21} \mathrm{H}_{23} \mathrm{NO}_{4}, \quad \mathrm{MW}=353.42\right)$, Monascorubramine $\left(\mathrm{C}_{23} \mathrm{H}_{27} \mathrm{NO}_{4}, \quad \mathrm{MW}=381.47\right)$, Monascin $\left(\mathrm{C}_{21} \mathrm{H}_{26} \mathrm{O}_{5}, \mathrm{MW}=358.43\right)$, Ankaflavin $\left(\mathrm{C}_{23} \mathrm{H}_{30} \mathrm{O}_{5}, \mathrm{MW}=386.49\right)$, Xanthomonascin $\mathrm{A}\left(\mathrm{C}_{20} \mathrm{H}_{22} \mathrm{O}_{7}, \mathrm{MW}=374.39\right)$, Xanthomonascin $\mathrm{B}$ $\left(\mathrm{C}_{22} \mathrm{H}_{26} \mathrm{O}_{7}, \quad \mathrm{MW}=402.44\right)$, Monascopyridine A $\left(\mathrm{C}_{21} \mathrm{H}_{25} \mathrm{NO}_{4}\right.$, $\mathrm{MW}=355.43)$, Monascopyridine $\mathrm{B}\left(\mathrm{C}_{23} \mathrm{H}_{29} \mathrm{NO}_{4}, \mathrm{MW}=383.49\right)$ and Yellow II $\left(\mathrm{C}_{23} \mathrm{H}_{28} \mathrm{O}_{5}, \mathrm{MW}=384.47\right)$. Separated pigments were also scanned by Photo Diode Array detector at 250-600 nm (SPDM20A).

\section{Results and discussion}

\subsection{Fungal growth and pigment production}

Growth phase is a key parameter in the production of secondary metabolites. In the first stage of fermentation, fungi utilize carbon and nitrogen from substrates for the primary metabolites synthesis, and then the secondary metabolites such as pigments are detected at the end of the fungal growth (Pattanagul et al., 2007). Fig. 1 shows the substrate-dependent growth of M. purpureus. The growth of fungi was fastest on rice, followed by DSG, WSG, Corn and SB substrates. The logarithmic phase on rice appeared at the time much faster than those on DSG, WSG, corn and $\mathrm{SB}$. The results suggested that $M$. pupureus poorly degraded non- 
(a)

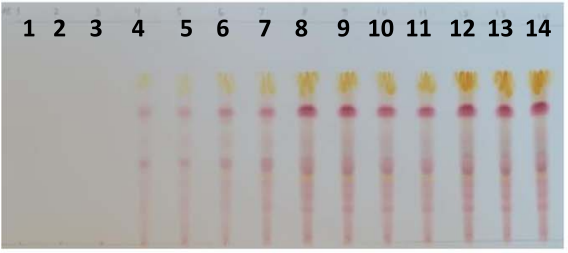

(b)

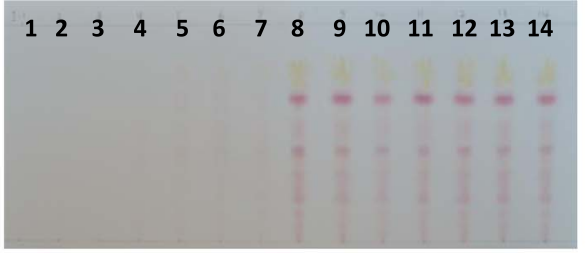

(c)

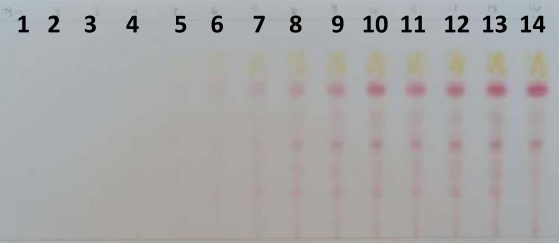

(d)

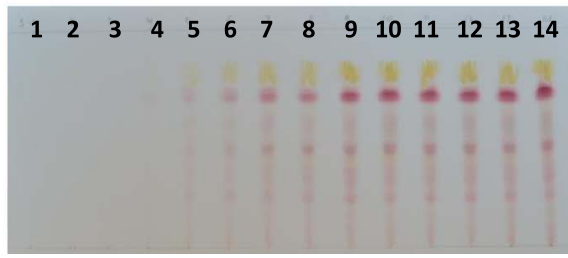

(e)

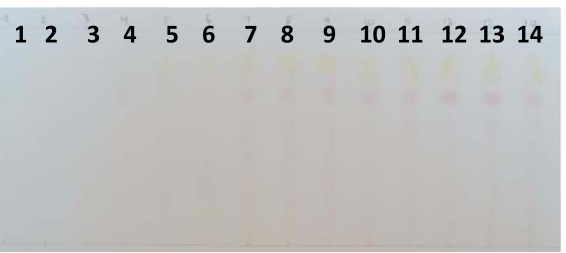

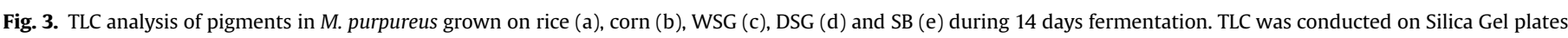

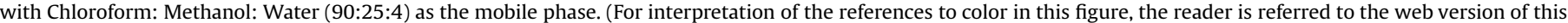
article.)

starch polysaccharides glucuronoarabinoxylans, mostly found at the endosperm cell wall of the grains of sorghum and corn (Taylor and Dewar, 2001). A previous work of Yang et al. (2015) also revealed that $M$. purpureus YY-1 is unable to degrade several oligosaccharides and polysaccharides such as D-xylan, arabinan and $1,4-\beta$-mannan, due to lacking genes for synthesis of $\beta$-xylosidase, $\alpha-\mathrm{N}$-arabinofuranosidase and mannan endo-1,4- $\beta$-mannosidase. It was also the case when $M$. purpureus was grown on the SB substrate which is rich in non-starch polysaccharides and poor in available N-containing compounds. In cases of rice and DSG grains, removal of the outer layers of the grains resulted in $M$. purpureus mycelia easier to penetrate into the grain to utilize the nutrients. Corredor et al. (2006) reported that the decorticating of sorghum grain results in greater starch loading and higher fermentation activity. The fungus grows slowly on SB that contains lower starch content than those of WSG and DSG (Srianta and Harijono, 2015). Moreover, SB contains a considerable amount of tannin that might inhibit fungi growth as reported by Taylor and Dewar (2001).

$M$. purpureus started to produce pigments at the end of the logarithmic phase (Fig. 2). TLC analysis (Fig. 3) showed the appearance of pigments at different periods of fermentation on each substrate i.e. at 4th day on rice, 5th day on DSG and longer period on other substrates. At the end of logarithmic phase, M. purpureus may change its central carbon metabolism and fatty acid degradation that influences on the pigment synthesis, through upregulation of the acetyl-CoA biosynthetic pathway as reported by Yang et al. (2015). The Fig. 2 show that the highest production of pigments was obtained on rice, followed by DSG > WSG > corn $>$ SB. Consistently, based on the total amount of 12 pigments (Table 1 ), the pigment production efficiency on DSG $>$ WSG $>$ corn $>$ SB were $85 \%>18 \%>7 \%>5 \%$, respectively, relative to the rice substrate. Conversely, biomass on DSG, WSG and corn were higher than that on rice (Fig. 1). These differences in the amount of pigments and in growth might be associated with a complex response to different carbon sources.

\subsection{Pigment composition}

Since the pigment produced by Monascus is a mixture of red, orange and yellow compounds, TLC analysis was performed to separate them (Fig. 3). As a result, there were several spots in different colors, confirming the mixture of compounds. The composition of pigment compounds was quantitatively determined by using LC-MS/MS. Fig. 4(a) and (b) show representatives of data of LC-MS/MS on rice substrate. Eleven pigments that have been reported (Miyake et al., 2008) plus 1 pigment with MW of $356.1 \mathrm{~g} /$ mol (+EMS $357.1 \mathrm{~m} / \mathrm{z}$, Fig. 4(c) and (d)) were identified. The latest pigment was the same as 1 of 4 newly identified pigments from Monascus-fermented dioscorea by Hsu et al. (2011), namely Monapilol $B\left(\mathrm{C}_{21} \mathrm{H}_{24} \mathrm{O}_{5}\right)$. Data of the 12 pigments detected on 5 different substrates and commercial Monascus pigments (Beni Koji Pigments) are summarized in Table 1. Six well-known pigments i.e. Rubropunctamine, Monascorubramine, Rubropunctatin, Monascorubrin, Monascin and Ankaflavin were detected.

Rubropunctamine (red pigment) was a major pigment in rice, corn, DSG and WSG fermented-products (57-87\% in the total amount of all pigments). However, Yellow II (43\% in the total amount of Yellow II and the other 7 detected pigments) was a major pigment in SB-fermented product. The amount of $\mathrm{Ru}-$ bropunctatin in fermented-DSG was much higher than those in other fermented products. Regarding the biosynthesis pathway, it is believed that orange pigments are the first biosynthesis product, which can be transformed to red and yellow pigments (Chen et al., 2015; Shi et al., 2015). Biosynthesis of the orange pigment Rubropunctatin has allowed to propose that polyketide chromophore is derived from acetate and malonate through $\beta$-ketide pathway and $n$-hexanoylacetyl residue is synthesized through another pathway (Birch et al., 1962; Holker et al., 1964; Whalley, 1963; Hadfield et al., 1967; Feng et al., 2012). Lin et al. (1992) proposed that the red pigment Rubropunctamine is synthesized by transformation from orange pigment Rubropunctatin through Schiff base formation by replacing oxygen in the orange pigment with nitrogen of the primary amino group of various compounds such as amino acids, peptides and proteins. Since cereal grain substrates (rice, corn, WSG and DSG) contains higher protein level than SB substrate, red pigment Rubropunctamine levels (57-87\%) were much higher than that on SB (10\%). However, there are no previous report on biosynthesis of Yellow II, which found as major pigment in fermented-SB.

In relation to fermented products by $M$. purpureus for application as natural food colorants, the pigment composition data reflected that the fermented DSG, WSG and corn can be used for red pigment sources like a generally used fermented-rice, while the fermented-SB is a yellow pigment source. Based on the pigment composition and the previous reports on bioactivities of individual pigment compound, the fermented products of $M$. purpureus in this study seem to have potentials as bioactive compound sources for development of food supplement, functional food, and or medicine with antiinflammation, anticancer and antimicrobial activities. Fermented rice, DSG, WSG and corn contained 
Table 1

Composition of pigments in M. purpureus grown on rice, corn, WSG, DSG and SB.

\begin{tabular}{|c|c|c|c|c|c|c|c|}
\hline \multirow[t]{2}{*}{ No } & \multirow[t]{2}{*}{ Pigment } & \multicolumn{6}{|l|}{ Area (\%) } \\
\hline & & Rice & Corn & WSG & DSG & SB & BKP \\
\hline 1 & Rubropunctatin & $138.19(0.64)$ & $195.33(12.72)$ & $367.54(9.51)$ & 3358.00 (18.33) & $33.262(2.88)$ & 26.67 (19.95) \\
\hline 2 & Monascorubrin & $14.75(0.07)$ & $1.98(0.13)$ & $33.77(0.87)$ & $4.44(0.02)$ & n.d. (n.d.) & n.d. (n.d.) \\
\hline 3 & Rubropunctamine & $18895.00(87.37)$ & $875.98(57.03)$ & $2250.50(58.26)$ & $12131.00(66.21)$ & $115.12(9.96)$ & $65.78(49.22)$ \\
\hline 4 & Monascorubramine & $84.73(0.39)$ & $30.74(2.00)$ & $86.22(2.23)$ & $577.78(3.15)$ & n.d. (n.d.) & $4.44(3.32)$ \\
\hline 5 & Monascin & $418.77(1.94)$ & 36.77 (2.39) & 65.40 (1.69) & $341.59(1.86)$ & $4.44(0.38)$ & $0.61(0.45)$ \\
\hline 6 & Ankaflavin & $22.05(0.10)$ & $4.97(0.32)$ & $48.23(1.25)$ & $16.79(0.09)$ & $165.80(14.34)$ & n.d. (n.d.) \\
\hline 7 & Xanthomonascin A & $499.07(2.31)$ & $121.27(7.90)$ & $499.07(12.92)$ & $677.33(3.70)$ & $82.22(7.11)$ & $0.52(0.39)$ \\
\hline 8 & Xanthomonascin B & $30.11(0.14)$ & n.d. (n.d.) & $12.21(0.32)$ & $5.08(0.03)$ & n.d. (n.d.) & $5.43(4.07)$ \\
\hline 9 & Monascopyridine A & $20.32(0.09)$ & $3.17(0.21)$ & $6.22(0.16)$ & $32.22(0.18)$ & $1.84(0.16)$ & $1.48(1.11)$ \\
\hline 10 & Monascopyridine B & $17.08(0.08)$ & $1.73(0.11)$ & $42.02(1.09)$ & $2.96(0.02)$ & n.d. (n.d.) & $3.70(2.77)$ \\
\hline 11 & Yellow II & $32.79(0.15)$ & $2.96(0.19)$ & $40.36(1.05)$ & $18.91(0.10)$ & $500.79(43.32)$ & $12.96(9.70)$ \\
\hline \multirow[t]{2}{*}{12} & Monapilol B & $1454.00(6.72)$ & $161.11(17.00)$ & $411.30(10.65)$ & $1155.60(6.31)$ & $252.59(21.85)$ & $12.06(9.02)$ \\
\hline & Total & $21626.86(100)$ & $1526.01(100)$ & $3862.83(100)$ & $18321(100)$ & $1156.07(100)$ & $121.59(100)$ \\
\hline
\end{tabular}

Note: Area is peak area of + EMS $\left(\times 10^{3}\right)$.

$\%$, percent relative of each pigment per total of 12 pigments.

n.d.: not detected.

BKP, Beni Koji Pigments, commercial Monascus pigment product purchased from Kanto Chemical Co, Tokyo, Japan.

(a)

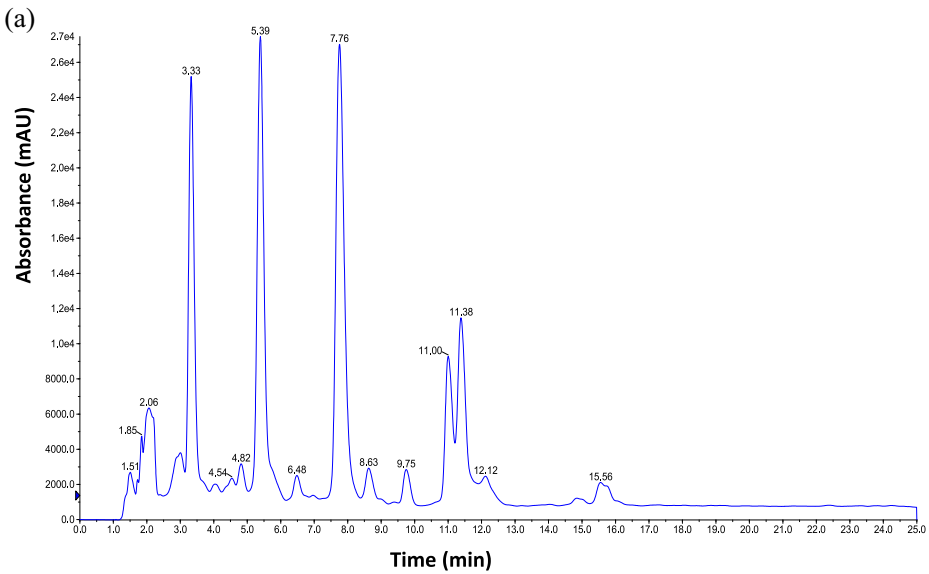

(b)

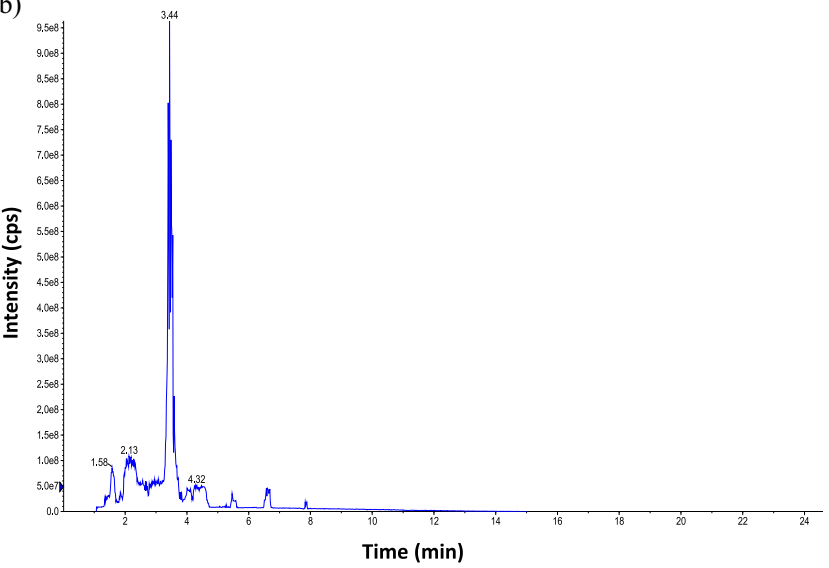

(c)

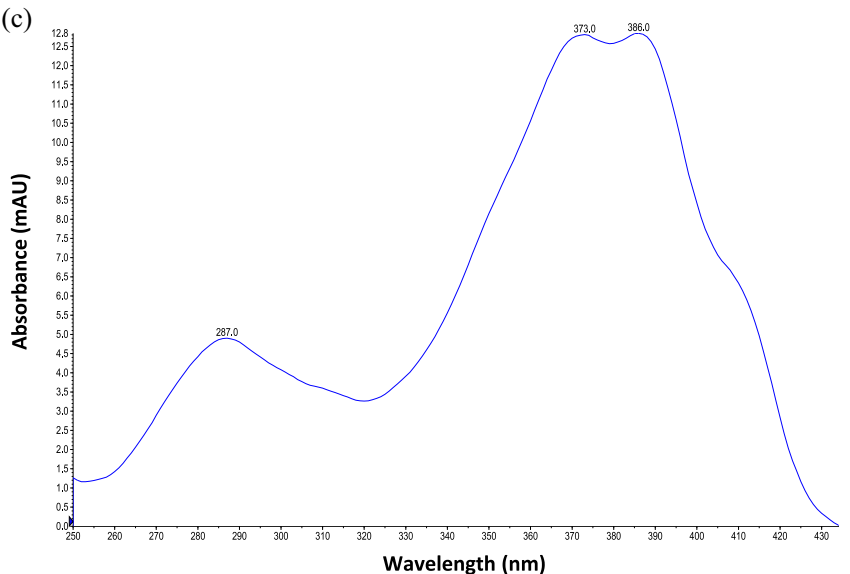

(d)

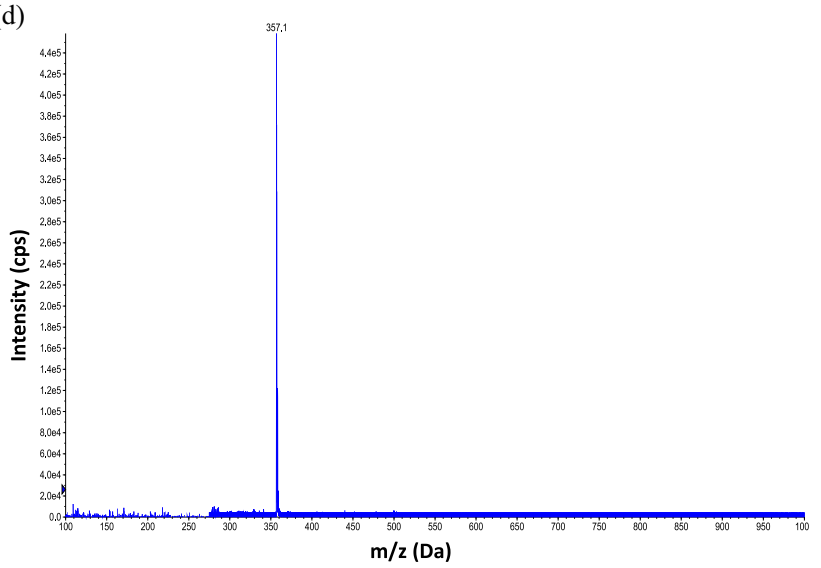

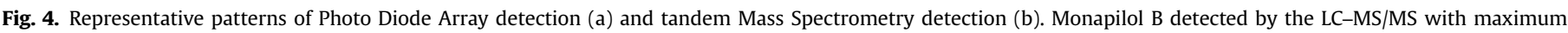
wavelength of $386 \mathrm{~nm}$ (c) and +EMS of $357.1 \mathrm{~m} / \mathrm{z}$ (d). All the data are pigments in M. purpureus grown on rice.

Rubropunctamine as a major pigment, which has been shown to have antiinflammation and anticancer activities (Akihisa et al., 2005a; Knecht and Humpf, 2006). Interestingly, the fermented DSG was rich in Rubropunctatin, which possesses antimicrobial activity (Martinkova et al., 1995), so the product is a good candidate as an antimicrobial source for the development of antibiotic and food preservative. Existence of Monapilol B as a major pigment in fermented rice and DSG also indicates possibility that the product can be a source for anticancer agent.

\section{Conclusions}

Monascus purpureus growth rate were found to depend on the substrate. The fastest fungal growth was occurred on rice, but the 
highest growth yield was on DSG. Outer layer of the cereal grains might inhibit the fungal mycelia penetration into the grains. Pigments production started to produce pigments at the end of logarithmic phase, with the fastest on rice (4th day), followed by DSG (5th day) and other substrates (longer periods of fermentation). The highest pigments production was detected on rice, followed by DSG > WSG > corn and SB. The fermented products except for fermented-SB contain similar kind of pigments including Rubropunctamine as a major pigment. DSG is a potential alternative to rice for the solid state fermentation of $M$. purpureus. The fermented products of $M$. purpureus are potential sources for food colorants as a natural pigment, in development of food supplement, functional food and application as medicines with anti inflammation, anticancer and antimicrobial activities.

\section{Acknowledgements}

This research was financially supported by Ministry of Research, Technology and Higher Education, Republic of Indonesia through BPP-DN scholarship with contract number of 1014/ UN10.14/KU/2013 and PKPI (sandwich-like) scholarship 2015 program with contract number of $162.4 / \mathrm{E} 4.4 / 2015$, and also by Yamaguchi University, Japan under MoU between Yamaguchi University and Brawijaya University. Thanks to Prof. Kenji Matsui, $\mathrm{PhD}$ and Tomoyuki Kosaka, PhD for technical supporting during this research work.

\section{References}

Akihisa, T., Tokuda, H., Ukiya, M., Kiyota, A., Yasukawa, K., Sakamoto, N., Kimura, Y. Suzuki, T., Takayasu, J., Nishino, H., 2005a. Anti-tumor initiating effects of monascin, an azaphilonoid pigment from the extract of Monascus pilosus fermented rice (red-mold rice). Chem. Biodivers. 2, 1305-1309.

Akihisa, T., Tokuda, H., Yasukawa, K., Ukiya, M., Kiyota, A., Sakamoto, N., Suzuki, T., Tanabe, N., Nishino, H., 2005b. Azaphilones, furanoisophthalides, and amino acids from the extracts of Monascus pilosus-fermented rice (red-mold rice) and their chemopreventive effects. J. Agric. Food Chem. 53, 562-565.

Babitha, S., Soccol, C.R., Pandey, A., 2006. Jackfruit seed - a novel substrate for the production of Monascus pigments through solid state fermentation. Food Technol. Biotechnol. 44 (4), 465-471.

Birch, A.J., Cassera, A., Firron, P., Holker, J.S.E., 1962. Studies in relation to biosynthesis part XXX*, rotiorin, monascin, and rubropunctatin. J. Chem. Soc., 3583-3586.

Carvalho, J.C., Oishi, B.O., Woiciechowski, A.L., Pandey, A., Babitha, S., Soccol, C.R. 2007. Effect of substrates on the production of Monascus biopigments by solidstate fermentation and pigment extraction using different solvents. Indian J. Biotechnol. 6, 194-199.

Chen, G., Shi, K., Song, D., Quan, L., Wu, Z., 2015. The pigment characteristics and productivity shifting in high cell density culture of Monascus anka mycelia. BMC Biotechnol. 15, 72 .

Corredor, D.Y., Schober, T., Wang, D., 2006. Effect of decorticating sorghum on ethanol production and composition of DDGS. Cereal Chem. 83 (1), 17-21.

Dufossé, L., Galaup, P., Yaron, A., Arad, S.M., Blanc, P., Chidambara, M.K.N., Ravishankar, G.A., 2005. Microorganisms and microalgae as sources of pigments for food use: a scientific oddity or an industrial reality? Trends Food Sci. Technol. 16, 389-406.

Feng, Y., Shao, Y., Chen, F., 2012. Monascus pigments. Appl. Microbiol. Biot. 96, 1421-1440.

Hadfield, J.R., Holker, J.S.E., Stanway, D.N., 1967. The biosynthesis of fungal metabolites. Part II. The $\beta$-oxo-lactone equivalents in rubropunctatin and monascorubrin. J. Chem. Soc., 751-755.

Hajjaj, H., Blanc, P.J., Groussac, E., Uribelarrea, J.L., Goma, G., Loubiere, P., 2000. Kinetic analysis of red pigment and citrinin production by Monascus ruber as a function of organic acid accumulation. Enzym. Microb. Technol. 27, 619-625.

Holker, J.S.E., Staunton, J., Whalley, W.B., 1964. The biosynthesis of fungal metabolites. Part I. Two different pathways to $\beta$-ketide chains in rotiorin. J. Chem. Soc., 16-22.

Hsu, Y.W., Hsu, L.C., Liang, Y.H., Kuo, Y.H., Pan, T.M., 2011. New bioactive orange pigments with yellow fluorescence from Monascus-fermented dioscorea. J. Agric. Food Chem. 59, 4512-4518.

Jou, P.C., Ho, B.Y., Hsu, Y.W., Pan, T.M., 2010. The effect of Monascus secondary polyketide metabolites, monascin and ankaflavin, on adipogenesis and lipolysis activity in 3 T3-L1. J. Agric. Food Chem. 58, 12703-12709.

Juzlova, P., Martinkova, L., Kren, V., 1996. Secondary metabolites of the fungus Monascus: a review. J. Ind. Microbiol. Biotechnol. 16, 163-170.

Knecht, A., Humpf, H.U., 2006. Cytotoxic and antimitotic effects of N-containing Monascus metabolites studied using immortalized human kidney epithelial cells. Mol. Nutr. Food Res. 50, 406-412.

Kongbangkerd, T., Tochampa, W., Chatdamrong, W., Kraboun, K., 2014. Enhancement of antioxidant activity of monascal waxy corn by a 2-step fermentation. Int. J. Food Sci. Tech. 49 (7), 1707-1714.

Kraboun, K., Tochampa, W., Chatdamrong, W., Kongbangkerd, T., 2013. Effect of monosodium glutamate and peptone on antioxidant activity of monascal waxy corn. Int. Food Res. J. 20 (2), 623-631.

Lin, T.F., Yakushijin, K., Büchi, G.H., Demain, A.L., 1992. Formation of water-soluble Monascus red pigments by biological and semisynthetic processes. J. Ind. Microbiol. 9, 173-179.

Martinkova, L., Juzlova, P. Vesely, D., 1995. Biological activity of polyketide pigments produced by the fungus Monascus. J. Appl. Microbiol. 79, 609-616.

Miyake, T., Zhang, M.Y., Sammoto, H., 2005. Analysis of red pigments produced by Monascus. Rep. Industrial Technology Center of Okayama Prefecture, vol. 31, pp. 75-76.

Miyake, T., Kono, I., Nozaki, N., Samoto, H., 2008. Analysis of pigment compositions in various Monascus culture. Food Sci. Technol. Res. 14 (2), 194-197.

Nimnoi, P., Lumyong, S., 2011. Improving solid-state fermentation of Monascus purpureus on agricultural products for pigment production. Food Bioprocess Technol. 4, 1384-1390.

Pattanagul, P., Pinthong, R., Phianmongkhol, A., Leksawasdi, N., 2007. Review of Angkak Production (Monascus purpureus). Chiang Mai J. Sci. 34 (3), 319-328.

Shi, Y.C., Liao, V.H.C., Pan, T.M., 2012. Monascin from red mold dioscorea as a nove antidiabetic and antioxidative stress agent in rats and Caenorhabditis elegans. Free Radic. Biol. Med. 52, 109-117.

Shi, K., Song, D., Chen, G., Pistolozzi, M., Wu, Z., Quan, L., 2015. Controlling composition and color characteristics of Monascus pigments by $\mathrm{pH}$ and nitrogen sources in submerged fermentation. J. Biosci. Bioeng. 120 (2), 145-154.

Srianta, I., Ristiarini, S., Nugerahani, I., Sen, S.K., Zhang, B.B., Xu, G.R., Blanc, P.J., 2014 Recent research and development of Monascus fermentation products. Int. Food Res. J. 21 (1), 1-12.

Srianta, I., Harijono, 2015. Monascus-fermented sorghum: pigments and monacolin K produced by Monascus purpureus on whole grain, dehulled grain and bran substrates. Int. Food Res. J. 22 (1), 377-382.

Su, N.W., Lin, Y.,L., Lee, M.H., Ho, C.Y., 2005. Ankaflavin from Monascus fermented red rice exhibits selective cytotoxic effect and induces cell death on Hep G2 cells. J. Agric. Food Chem. 53, 1949-1954.

Taylor, J.R.N., Dewar, J., 2001. Developments in sorghum food technologies. In: Taylor, S. (Ed.), Advances in Food and Nutrition Research vol. 43. Academic Press, San Diego, CA, USA, pp. 217-264.

Vendruscolo, F., Tosin, I., Giachini, A.J., Schmidell, W., Ninow, J.L., 2014. Antimicrobial activity of monascus pigments produced in submerged fermentation. J. Food Process. Pres. 38, 1860-1865.

Whalley, W.B., 1963. The sclerotiorin group of fungal metabolites: their structure and biosynthesis. Pure Appl. Chem. 7, 565-587.

Yang, Y., Liu, B., Du, X., Li, P., Liang, B., Cheng, X., Du, L.C., Huang, D., Wang, L., Wang, S., 2015. Complete genome sequence and transcriptomics analyses reveal pigment biosynthesis and regulatory mechanisms in an industrial strain, Monascus purpureus YY-1. Sci. Rep. 5, 8331. http://dx.doi.org/10.1038/srep08331.

Zheng, Y.Q., Xin, Y.W., Shi, X.A., Guo, Y.H., 2010. Anti-cancer effect of rubropunctatin against human gastric carcinoma cells BGC-823. Appl. Microbiol. Biot. 88, 1169-1177. 